\title{
WORK AND SOCIAL PROTECTION IN ASIA AND THE PACIFIC DURING THE FOURTH INDUSTRIAL REVOLUTION
}

Duncan Campbell

NO. 65

March 2020

\section{ADB SUSTAINABLE DEVELOPMENT WORKING PAPER SERIES}





\section{ADB Sustainable Development Working Paper Series}

\section{Work and Social Protection in Asia and the Pacific during the Fourth Industrial Revolution}

Duncan Campbell

No. 65 | March 2020
Duncan Campbell was formerly a director of Global Mega-Trends at the International Labour Organization.

$\mathrm{He}$ is currently a visiting professor at Cornell University. 
(C) 2020 Asian Development Bank 6 ADB Avenue, Mandaluyong City, 1550 Metro Manila, Philippines

Tel +632 8632 4444; Fax +63286362444

www.adb.org

Some rights reserved. Published in 2020.

Publication Stock No. WPS200100-2

DOI: http://dx.doi.org/10.22617/WPS200100-2

The views expressed in this publication are those of the authors and do not necessarily reflect the views and policies of the Asian Development Bank (ADB) or its Board of Governors or the governments they represent.

ADB does not guarantee the accuracy of the data included in this publication and accepts no responsibility for any consequence of their use. The mention of specific companies or products of manufacturers does not imply that they are endorsed or recommended by ADB in preference to others of a similar nature that are not mentioned.

By making any designation of or reference to a particular territory or geographic area, or by using the term "country" in this document, $A D B$ does not intend to make any judgments as to the legal or other status of any territory or area.

This work is available under the Creative Commons Attribution 3.0 IGO license (CC BY 3.0 IGO)

https://creativecommons.org/licenses/by/3.0/igo/. By using the content of this publication, you agree to be bound by the terms of this license. For attribution, translations, adaptations, and permissions, please read the provisions and terms of use at https://www.adb.org/terms-use\#openaccess.

This CC license does not apply to non-ADB copyright materials in this publication. If the material is attributed to another source, please contact the copyright owner or publisher of that source for permission to reproduce it. ADB cannot be held liable for any claims that arise as a result of your use of the material.

Please contact pubsmarketing@adb.org if you have questions or comments with respect to content, or if you wish to obtain copyright permission for your intended use that does not fall within these terms, or for permission to use the ADB logo.

The ADB Sustainable Development Working Paper Series presents data, information, and/or findings from ongoing research and studies to encourage exchange of ideas and elicit comment and feedback about development issues in Asia and the Pacific. Since papers in this series are intended for quick and easy dissemination, the content may or may not be fully edited and may later be modified for final publication.

Corrigenda to ADB publications may be found at http://www.adb.org/publications/corrigenda. 


\section{CONTENTS}

TABLES AND FIGURES IV iv

ACKNOWLEDGMENTS V V v

EXECUTIVESUMMARY vi

I. INTRODUCTION 1

A. The Quantity and Quality of Jobs $\quad 2$

B. The Location and Nature of Work $\quad 8$

II. SOCIAL PROTECTION WITHIN THE FOURTH INDUSTRIAL REVOLUTION CONTEXT 9

A. Protected Mobility $\quad 10$

B. Unemployment Insurance $\quad 10$

C. Citizenship Approach 11

III. SOCIAL PROTECTION AND EMPLOYMENT 13

$\begin{array}{ll}\text { IV. CONCLUSIONS } & 16\end{array}$ 


\section{TABLES AND FIGURES}

\section{Tables}

1 Fourth Industrial Revolution Changed Parameters 2

2 Key Messages of the OECD Trade Union Advisory Committee 6

3 Extending Social Insurance Coverage in Asia and the Pacific $\quad 10$

\section{Figures}

1 Socioeconomic Groups from the International Labour Organization's Key Indicators of the Labor Market Global Data Set

2 Vulnerable Employment in the Labor Force in Asia and the Pacific

3 Estimated Share of Employment Susceptible to Automation

4 Levels of Investment in the 10 Highest-Spending, Tax-Financed, Inclusive Pensions and Poor Relief Schemes

5 Social Protection Needs over a Life Cycle 


\section{ACKNOWLEDGMENTS}

The author is grateful for comments received from Sri Handayani and Sameer Khatiwada of the Asian Development Bank, as well as those received from colleagues at the International Labour Organization. Students at Cornell University's School of Industrial and Labor Relations also shared their insights on an earlier draft. 


\section{EXECUTIVE SUMMARY}

The universal right to social protection remains elusive in Asia and the Pacific, as in the rest of the world. In developing Asia and the Pacific, most new entrants to the labor market do so informally; beyond the informal economy, the nature of work in the region is often in temporary contracts. Regular, full-time employment in the formal economy encompasses a minority of labor market participants, so the majority of those working are usually without social protection, which has been traditionally associated with labor market participation.

Against this background, the Fourth Industrial Revolution is beginning to emerge in the region, that is, the convergence of the digital economy-which is rapidly evolving and eroding the barriers of physical space and time-with the real economy of material things. Unquestionably, however, the region's labor market policies, regulations, and institutions lag behind this change, as do its labor market participants. In examining anticipated changes in Asia and the Pacific due to the advent of this revolution, this report finds four significant changes to the labor market that will occur-a labor market that has yet to come to terms with its social protection challenges.

The first, the quantity of work, will result in technologically driven job loss, job polarization, and greater labor market churning. The second, the quality of work, will be impacted, as it is unclear how hours, wages, pensions, and sick days will be determined in the future. Labor market statuses that differ from full-time, standard jobs require that these statuses be protected so that labor market mobility is not a barrier, but an option.

Thirdly, the Fourth Industrial Revolution will change the location of work. Many jobs in the digital economy delink the relevance of physical location from work performance. In other words, the concept of physical proximity to a workplace shared by other workers has diminished in significance, whereas a common workplace had been a traditional locus of common labor market regulation. Finally, the nature of work is changing; a job is defined as a compilation of tasks, many of which will either be substituted by or assisted by technological change. Today, the bias is toward higher skills, such as computer literacy and creative problem solving, achieved through education and training systems.

Labor markets in Asia and the Pacific are characterized by nonstandard forms of employment (NSFEs), an emerging share of labor force participation in developed economies. While this model shows signs of receding in developed countries where NSFEs do not have the full extent of social protection provided through the labor market, this trend is not yet visible in Asia and the Pacific. Instead, the growing middle class in the most dynamic economies is an outcome of the increasing share of wage-earning employment in the labor market. They are not entrepreneurs; they are wage earners attached to their jobs and the social protection that the jobs bring-a model similar to those of developed countries where social protection is closely tied to employment.

The challenge for work-related social protection is to advance in the protection of contractual forms currently unprotected in the region. Although most of these forms of labor have little to do with the Fourth Industrial Revolution; over time, many more will. 


\section{INTRODUCTION}

1. The majority of the world's population, mostly in developing countries and areas, still has no access to formal systems of social protection, the consequence of tenuous or no ties to the formal economy, government fiscal constraints, and poor administrative capacity to deliver protection effectively. Demographic pressures also frustrate access; the aging of societies, coupled with increasing longevity, result in declining dependency ratios that weaken the tax base on which the provision of oldage pensions rely. These pressures also reduce the extent and efficacy of prenatal and child health care, for example.

2. For the majority of the working-age population in Asia and the Pacific, social protection coverage is not linked to labor market participation, or even to the state. Many do not work in the formal economy, and contract labor abounds. This situation ironically mirrors the many changes to the labor market that are being brought about by the Fourth Industrial Revolution in developed parts of the globe; this revolution will also soon dawn upon developing regions, such as Asia and the Pacific, that already have these weak social protection systems.

3. The Asian Development Bank (ADB) states that

...the First Industrial Revolution [was] driven by the rise of steam power, railways and mechanized forms of production. The Second Industrial Revolution took hold in 1890 with the rise of electricity and new approaches to manufacturing based on assembly lines and mass production. The Third Industrial Revolution emerged in the 1960s with the rise of semiconductors and the spread of computers and the internet. Today, we face a Fourth Industrial Revolution. Building on the digital technologies of the Third Industrial Revolution, it is powered by a wide range of new breakthroughs not only in the digital realm (such as artificial intelligence) but also in the physical realm (new materials), as well as the biological realm (bio-engineering). These new technologies are revolutionary due to the speed, breadth and depth of the anticipated change they will bring. ${ }^{1}$

4. This current wave of technological change, distinct from previous eras, is rapid and nonlinear:

...new technologies are emerging faster, being adopted more quickly and delivering greater impact than ever before. Fixed-line telephones, first developed in 1878, took 75 years to reach 100 million users. Mobile phones, which emerged in 1979, took 16 years to reach 100 million users. The internet, which was launched to the public in 1990, took six years to reach 100 million users. The Apple App Store, unveiled in 2008, took just three years to reach 100 million users. $^{2}$

5. Over much of the 20th century, enterprises were marked by brick-and-mortar physical locations; aggregated workforces under one roof; established wages for a set number of working hours and wage premiums for overtime work; and employment security, with procedures and indemnities (i.e., severance pay) guaranteed for dismissals. Workers benefitting from these conditions were those in regular fulltime employment. Table 1 illustrates how the Fourth Industrial Revolution is now impacting the quantity, quality, location, and nature of work.

1 ADB and World Economic Forum. 2017. ASEAN 4.0: What Does the Fourth Industrial Revolution Mean for Regional Economic Integration? Manila: ADB. p. 10.

2 Footnote 1, p. 11. 
Table 1: Fourth Industrial Revolution Changed Parameters

\begin{tabular}{|l|l|}
\hline Quantity of Jobs & $\begin{array}{l}\text { - Job polarization thesis; the disappearance of routine, formerly middle-class jobs } \\
\text { - Technology's substitution of labor; robots and algorithms displacing human labor }\end{array}$ \\
\hline Quality of Jobs & $\begin{array}{l}\text { - Pay, security, and self-employment } \\
\text { - Data and personal privacy } \\
\text { - Future and funding of social protection }\end{array}$ \\
\hline Location of Work & - Delink the relevance of physical location from work performance \\
\hline Nature of Work & $\begin{array}{l}\text { - Computer-assisted human labor } \\
\text { - New occupations unforesen 2-3 decades ago }\end{array}$ \\
\hline
\end{tabular}

Source: Author.

\section{A. The Quantity and Quality of Jobs}

6. Of the four dimensions in Table 1, the quantity of work in the future most often dominates concerns about the Fourth Industrial Revolution. As the McKinsey Global Institute noted:

The world of work is in a state of flux.... There is growing polarization of labor-market opportunities between high- and low-skill jobs, unemployment and underemployment especially among young people, [and] stagnating incomes for a large proportion of households...public debate rages about the future of work and whether there will be enough jobs to employ everyone. ${ }^{3}$

7. Job polarization refers to the decline of middle-class jobs and is usually measured in terms of earnings and vacancies. ${ }^{4}$ The hypothesis holds that these jobs are declining because many are routine, and computers, algorithms, and robots can act as substitutes. Many find evidence supporting this "hollowing out" phenomenon through differential rates of job growth by earning quintiles. ${ }^{5}$ Evidence for the United States shows a lower rate of earnings-related growth of middle-class jobs relative to the tails of the earnings distribution. While concerns over job polarization have indeed been particularly acute in the developed world, the World Bank found evidence of the same in a sample of developing countries. ${ }^{6}$

8. Thus, while there will never be a paucity of work, the Fourth Industrial Revolution could portend an absolute paucity of jobs, both in the developed and developing world. New technologies will displace jobs; these should not, however, be recorded as job dismissals, but as the decline of vacancies in those middle-class jobs upon which industrial societies were built, given that middle-class jobs are disproportionately those that are routine and thus can be codified. Yet those displaced from the opportunities for such jobs are more likely to move down the occupational hierarchy than to climb into more highly skilled, nonroutine work; as such, job polarization is also a prescription for income polarization.

3 McKinsey Global Institute. 2016. Technology, Jobs, and the Future of Work. https://www.mckinsey.com/featured-insights/ employment-and-growth/technology-jobs-and-the-future-of-work].

4 M. Goos. and A. Manning. 2007. Lousy and Lovely Jobs: The Rising Polarization of Work in Britain. Review of Economics and Statistics. 89 (1). pp. 118-133; and D. Autor, F. Levy, and R. Murnane. 2003. The Skill Content of Recent Technological Change: An Empirical Exploration. The Quarterly Journal of Economics. 118 (4). pp. 1279-1333.

5 M. Dvorkin and A. Bharadwaj. 2019. Labor Market Polarization across the U.S. On the Economy Blog. Federal Reserve Bank of St. Louis. 4 February. https://www.stlouisfed.org/on-the-economy/2019/february/labor-market-polarization-us.

6 World Bank. 2016. World Development Report 2016: Digital Dividends. Washington, DC: World Bank. 
9. The argument that technological substitution for human labor is concentrated in middle-class occupations conflicts with the decline in poverty and growth of the middle class witnessed in Asia and the Pacific (Figure 1). The middle class can grow in absolute terms and still decline in relative terms (i.e., as a share of the labor force), if, for example, the share of the working poor or the wealthy is rising at a higher rate. In Asia and the Pacific, this is true for the wealthy but not for the working poor, although poverty, particularly extreme poverty, has substantially declined in share (Figure 2).

10. It is anticipated that in general, the Fourth Industrial Revolution guarantees that labor market churning will increase, with young people changing jobs at least three times over the next decade, as their current jobs are displaced by technology. One article observed that technology could substitute human labor in $47 \%$ of jobs in the United States now or in the near future. 7 This, then, would be part of a more secular trend in which long-term employment is interrupted by the absence of such security thus exposing the active labor force to gaps in social protection.

11. The Organisation for Economic Co-operation and Development (OECD) found that technologies' substitution for human labor may apply to only $9 \%$ of the workforce, however, and that technology was more likely to complement rather than substitute human labor. ${ }^{8}$ Another insight is the distinction between a "job" and the various "tasks" that comprise it; some of these tasks are becoming increasingly computer-assisted or disappearing, while the job itself remains.

12. Labor substitution is becoming most evident in manufacturing employment; even traditionally labor-intensive manufacturing, like footwear, is becoming less so in high labor-cost countries. Both Nike and Adidas have recently opened fully automated plants in Western Europe. However, there is

\section{Figure 1: Socioeconomic Groups from the International Labour Organization's Key Indicators of the Labor Market Global Data Set}

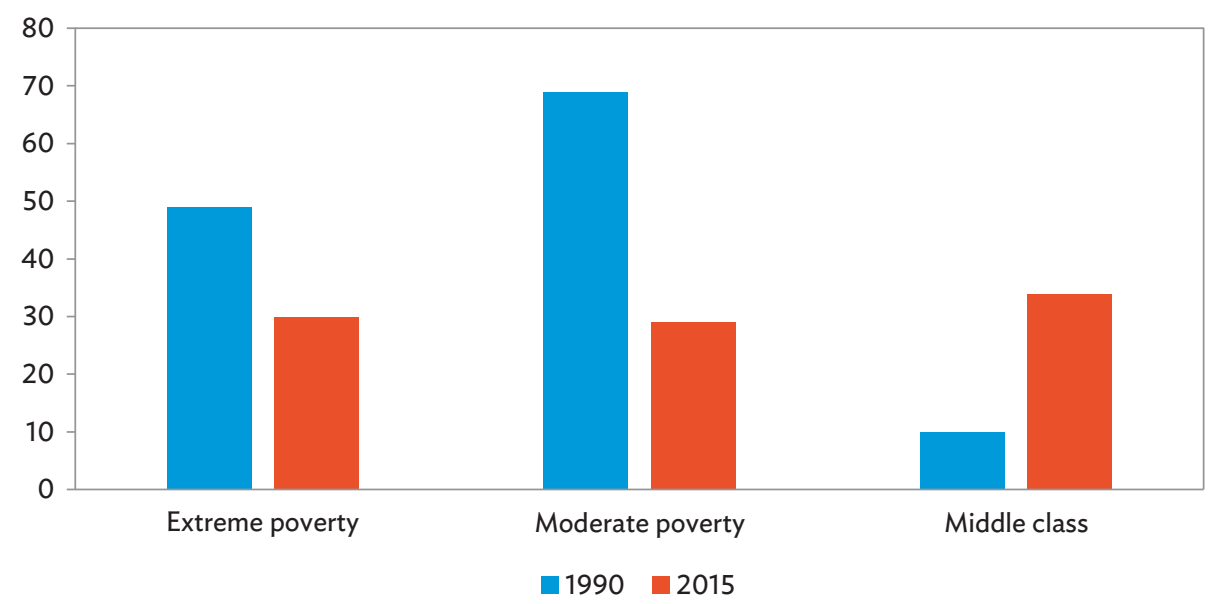

Source: Author's calculations based on the International Labour Organization's Key Indicators of the Labor Market, 9th Edition, 2015 and updated online.

7 C. Frey, and M. Osborne. 2013. The Future of Work: How Susceptible Are Jobs to Computerisation? Technological Forecasting and Social Change. 114 (C). pp. 254-280.

8 OECD. 2016. New Markets and New Jobs in the Digital Economy. Presentation 4.1 during the OECD Ministerial Meeting on the Digital Economy: Innovation, Growth, and Social Prosperity. Cancun, Mexico. 21-23 June. 


\section{Figure 2: Vulnerable Employment in the Labor Force in Asia and the Pacific}

$(\%)$

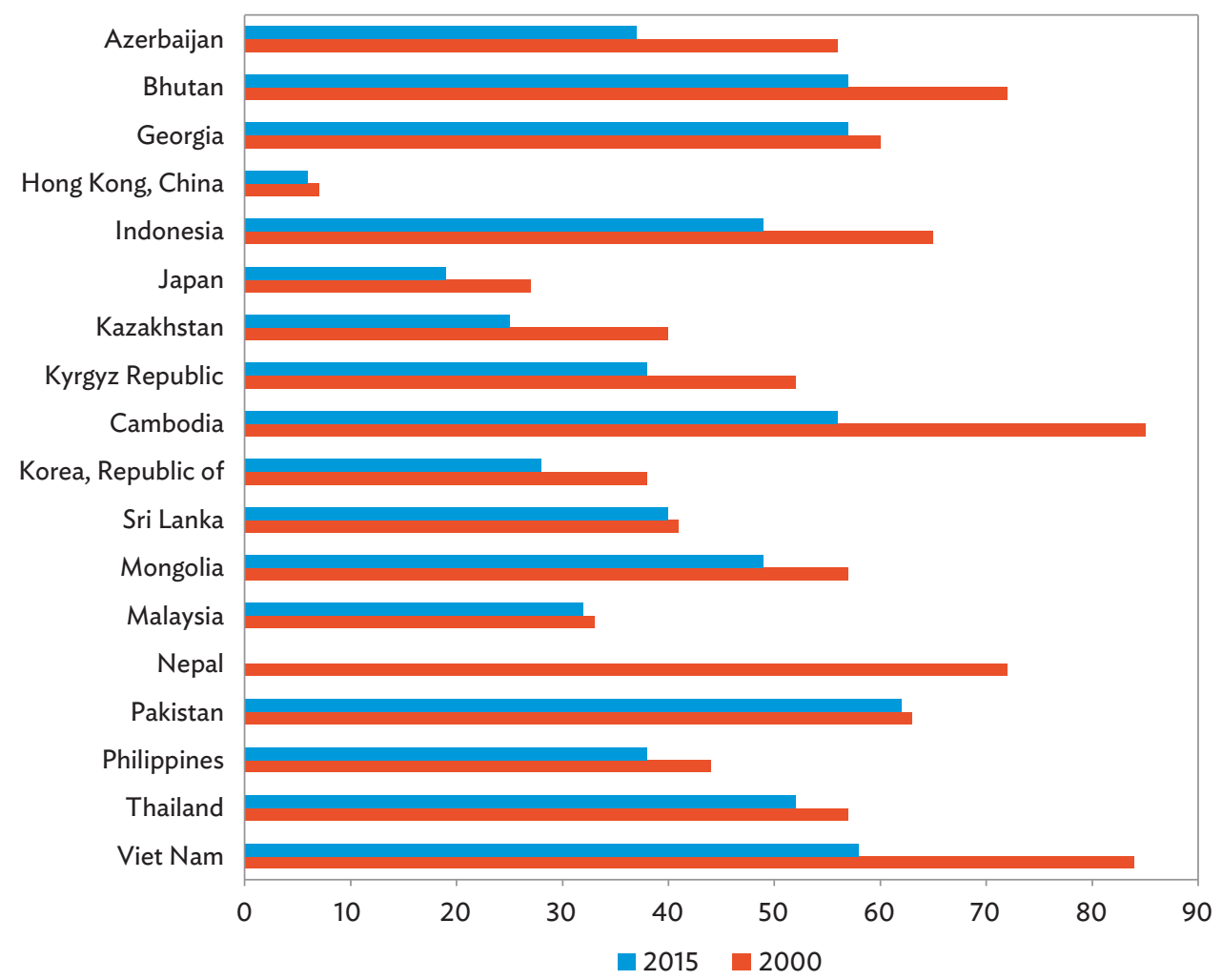

Note: "Vulnerable employment" is defined by the International Labour Organization as the share of own-account and unpaid family workers in the labor force. It is so defined as these workers are those with neither employment security nor social protection. Source: Author's calculations based on the International Labour Organization's Key Indicators of the Labor Market, 9th Edition, 2015 and updated online.

also evidence of labor substitution coinciding with employment growth; for example, Amazon's highly automated distribution facilities have lowered costs and increased productivity to such a degree that employment in the company has increased. The line between whether robotics is a substitute or complement for human labor, therefore, is not clear.

13. Focusing on job loss due to the Fourth Industrial Revolution is an extreme conclusion to draw for two reasons. Direct, technology-induced job loss does not take into account indirect job creation elsewhere in the economy. Gains in productivity from robotics translate into higher productivity and lower costs elsewhere in the economy as well as a gain in real income, which is job boosting. Indeed, simulations using the Groningen input/output tables suggest that multiplier effects from roboticsinduced direct job loss overwhelm the job loss effect with indirect job gains elsewhere in the economy. ${ }^{9}$ The literature on structural economics draws similar conclusions; it is not unusual for a dynamic sector of an economy not to be the sector in which job growth is occurring. ${ }^{10}$

9 ADB. 2018. Asian Development Outlook 2018: How Technology Affects Jobs. Manila.

10 L. Taylor. 2004. Reconstructing Macroeconomics: Structuralist Proposals and Critiques of the Mainstream. Cambridge, MA: Harvard University Press. 
14. Another force surrounding the Fourth Industrial Revolution is the change in status in employment, which is shifting the qualities associated with work. There are two broad statuses in employment: wage earners and the self-employed. Historically, there has been a positive correlation between the share of wage earners in the economy and the level of economic development as measured by a standard of national wealth (e.g., gross domestic product [GDP] or gross national income [GNI] per capita). That correlation still holds, including in Asia and the Pacific, where the poorer the country, the higher the share of the agricultural sector and share of nonagricultural self-employment. As stated, the region's development has focused on a rising middle class, attendant upon economic growth. Because middleclass workers tend to be wage earners, wage earners as a share of the labor force in Asia and the Pacific has risen.

15. With the rapid onset of technological change, three associated changes are affecting labor markets and thus the workforce. First, digital technology is behind a substantial decline in transaction costs. As an example, a farmer living at a distance from a market in which he or she may sell produce can now, with a smartphone, know the demand for output and price it fetches, overcoming the barriers of time and distance to acquire this information. Second, fast-paced technological change has decreased product life cycles across the gamut of manufactured goods (e.g., a 1-year-old mobile phone is rapidly reaching obsolescence). Third, digital technologies, in overcoming barriers to time and location, facilitate the ability to contract with a virtual workforce anywhere.

16. The consequences of these transformative changes on the labor market are both positive and negative. The speed of product market change makes employers less willing to invest in employment security, as they are uncertain as to the quantity of workers and future skills that they possess. Firms thus face a "make or buy" or "own or rent" decision relative to their commitment to employment security. This is a reason for the rise of nonstandard jobs with limited security, known as nonstandard forms of employment (NSFEs). A corollary of the declining commitment to employment security is a deteriorating commitment to training. With NSFEs, many firms prefer to "buy" the skills that they need from the marketplace rather than invest in-house, questioning how the NSFE workforce will acquire skills. ${ }^{11}$

17. The Trade Union Advisory Committee of OECD held the Trade Union Forum on Digitalization in February 2017, intended as an input to a current, 2-year horizontal project on Seizing the Benefits of Digitalization for Growth and Well-Being. The forum focused on a just transition to a digital economy, having called upon OECD ministers "to develop a policy framework to ensure that the expansion of the digital economy contributes to inclusive growth."12 It stated that policies need to ensure that technology has positive impacts on growth, job quality, and employment creation, and that digitalization and innovation must contribute to better living conditions and more equal societies. ${ }^{13}$ Table 2 highlights key conclusions of the forum.

11 P. Cappelli. 2015. Why Good People Can't Get Jobs: The Skills Gap and What Companies Can Do About It. Philadelphia: Wharton Digital Press.

12 Trade Union Advisory Committee. 2017. Digitalization and the Digital Economy: Trade Union Key Messages. Paris: OECD.

13 Footnote 12. 
Table 2: Key Messages of the OECD Trade Union Advisory Committee

\begin{tabular}{|c|c|}
\hline Job quality & $\begin{array}{l}\text { - Create or maintain jobs in occupations that are less open to automation and digitalization. } \\
\text { - Integrate provisions on digitalization and technological diffusion in collective-bargaining } \\
\text { agreements and in firm-level information and consultation mechanisms. } \\
\text { - Use data to avoid work intensification and standardization. } \\
\text { - Ensure strict compliance with working time regulations and the "right to disconnect." } \\
\text { - Ensure regulation on mobile work to prevent abuse. } \\
\text { - Strengthen or introduce worker data protection, thereby restricting surveillance and } \\
\text { automated evaluation to only work-relevant activities within legitimate boundaries of } \\
\text { employee supervision, also adapted to mobile and platform work. }\end{array}$ \\
\hline $\begin{array}{l}\text { Skills development and } \\
\text { effective training systems }\end{array}$ & $\begin{array}{l}\text { - Give a training guarantee to all workers, and provide continuous on-the-job training. } \\
\text { - Anticipate future competency needs, and update curricula of education and training systems } \\
\text { - Ensure that massive, open online courses are accredited and licensed. } \\
\text { - Ensure that teachers have access to training. } \\
\text { - Foster cross-disciplinary skills, basic numeracy and literary skills, digital literacy, and cognitive } \\
\text { and social skills. } \\
\text { - Promote enrollment in science, technology, engineering, and mathematics (STEM) as well as } \\
\text { information and communication technology-related technical and vocational education and } \\
\text { training and coding skills, and ensure women's access. }\end{array}$ \\
\hline $\begin{array}{l}\text { On challenges of work on } \\
\text { online platforms }\end{array}$ & $\begin{array}{l}\text { - For workers who are dependent upon a single employer, guarantee the right to salaried } \\
\text { employment contracts, including minimum wage, pay, occupational safety and health, } \\
\text { adequate pensions, unemployment and health coverage, minimum paid sick leave, paid } \\
\text { vacation, and maternity and paternity benefits. } \\
\text { - Ensure the right to freely organize, take collective action, and negotiate collective agreements } \\
\text { and consultation mechanisms on prices and terms of service. } \\
\text { - Ensure that competition laws do not impede the self-employed from joining a trade union. } \\
\text { - Identify disguised self-employment and dependent self-employment. } \\
\text { - Pay minimum rates on an hourly basis and not below national minimum wages. } \\
\text { - Guarantee universal and portable social protection systems. }\end{array}$ \\
\hline
\end{tabular}

Source: Trade Union Advisory Committee. 2017. Digitalization and the Digital Economy: Trade Union Key Messages. Paris: OECD.

18. The Business 20 (B20) and the Labour 20 (L20) of the 2017 G20 Summit in Hamburg drew conclusions similar to those in Table 2, under the heading "Sustainable growth, decent work and social cohesion in the digital economy: a common message."14

19. Table 2 can be read as a trade union view of standard protections that are most at risk by technological change. Responses include the promotion of jobs that are not susceptible to automation; concerns over worker surveillance and privacy, now capable of monitoring; a right to training, not as onset to a career, but continuously, as skills erode; and a concern over the self-employed, their protection, their ability to unionize, and their long-term viable association with the new labor market.

14 G20. 2017. G20 Leaders' Declaration: Shaping an Interconnected World. Hamburg. 
20. ILO also offers four main policy recommendations for how NSFEs can be made decent:

(i) Plug regulatory gaps. Policies should ensure equal treatment among workers, regardless of their contractual arrangements; establish minimum guaranteed hours for on-call workers; ensure worker input in their work schedules; address employment misclassification; and restrict some uses of NSFEs to address abuse, such as not allowing temporary agency workers to replace workers during strikes. For workers in employment relationships involving multiple parties, there is a need to ensure that employers using agency or leased workers are held responsible for their safety and health and are also liable for payment of wages and social security benefits if the contracting firm becomes insolvent.

(ii) Strengthen collective bargaining. Collective bargaining can take into account circumstances of a sector or enterprise and is thus well-suited for addressing the needs of both employers and workers. Collective bargaining should be strengthened by building the capacity of unions to represent workers in NSFEs, and by ensuring that all workers have access to freedom of association and collective bargaining rights. Where it exists, the extension of collective agreements to all workers in a sector or occupational category is a useful tool for reducing insecurities and improving working conditions in NSFEs.

(iii) Improve social protection coverage. Social security systems should be adopted to increase the coverage of workers in NSFEs, by lowering thresholds on minimum hours, earnings, or duration of employment; making systems more flexible regarding contributions required to qualify for benefits, allowing for interruptions in contributions; and enhancing the portability of benefits; as well as complementing social security with universal policies guaranteeing a basic level of social protection.

(iv) Establish comprehensive employment and social policies that support the labor market. Policies must support employment creation, provision of public care services, and a greater ability to take parental and elder care leave as well as training and life-long learning. These policies help address shortcomings in the current design of standard jobs, thereby providing workers with family responsibilities a greater choice in whether to engage in standard or nonstandard work. ${ }^{15}$

21. NSFEs can offer greater options for employers in how they organize work, but when there are distinctions between entitlements that accrue, incentives are often created for employers to use these arrangements as a way to reduce labor costs rather than as a legitimate response to specific demands in production. Thus, measures that narrow the differences between standard and nonstandard jobs should be implemented, so that employers' need for flexibility can be met but not at the expense of fair competition or workers' well-being. ${ }^{16}$

22. Simply providing a universal basic income to a country or area's working-age population is not sufficient, as it fails to address the many dimensions of work that affect daily lives. The labor market needs to be regulated to ensure that workplaces are safe and healthy, there are limits on the hours worked, at least the minimum wage is earned, there is equal pay for work of equal value, and all are protected from discrimination.

15 International Labour Organization. 2016. Non-Standard Employment around the World: Understanding Challenges, Shaping Prospects. Geneva.

16 Government of Italy, Senate of the Italian Republic, 11th Labour and Social Security Committee. 2017. The Impact of the Fourth Industrial Revolution on the Jobs Market. Rome. 


\section{B. The Location and Nature of Work}

23. Technological drivers have the positive effect of increasing the ways in which a person can engage the labor market, which has resulted in a gig economy, a free market system in which temporary positions are common as organizations contract with independent workers for short-term engagements. Persons using digital platforms, often away from a traditional shared physical office space, can bid to offer services for a finite duration, becoming self-employed with greater personal say in allocating time between market and nonmarket activities. As a consequence, there is "far greater opportunities for workers individually and collectively to find the entrepreneur most capable of generating value from their labor, creating more competition on the jobs market between entrepreneurs, and potentially leading to a strengthening of the most highly qualified workers' bargaining powers" (footnote 16). Economic theory finds this virtual market for labor productivity-enhancing at the individual and aggregate levels.

24. Data for the United States suggest that the typical worker in the gig economy also has a more standard form of employment (i.e., a "day job") where benefit protections exist. For those whose principal work is in the gig economy, however, the alternative is unemployment. In this way, this form of participation in the digital economy parallels the traditional labor markets of developing countries, where the high share of self-employment reflects the absence of good jobs in the formal economy rather than a taste for entrepreneurship.

25. A host of risks to worker protection is thus arising in the gig economy. As such, self-employment can convert what was once a labor contract into a commercial contract in which those supplying labor become responsible not only for their income generation and continuity of work, but for their health, old-age pension, and working time-protections usually afforded by regular contracts of employment. These dynamics call into question the ability of unemployment and training systems to respond.

26. The logic of the Fourth Industrial Revolution is boundaryless, overlapping with the understanding of globalization as "fiercer competition among workers, including but not limited to workers resident in countries that are far apart, reduc[ing] the effectiveness of the protection techniques on which labor law regulations were based during the last century, to the detriment of the 'lower portion' or 'lower half' of each professional category" (Footnote 16). Widening income gaps and greater transitional unemployment or underemployment are consequences of these economic changes. ${ }^{17}$ Social protection systems will need to respond; for example, there will be more frequent spells of unemployment for the digital platform worker in the gig economy moving from project to project.

27. In Asia and the Pacific, labor market regulation remains exclusive, failing to cover the majority of the labor force, thereby widening the gap between de jure and de facto regulation. Industrial relations are notoriously weak, characterized by low trade union density and low levels and coverage of collective agreements. There is no interlocutor in a labor market subject to disruptive and rapid change. While informality and self-employment are hurdles to trade union organization, the segmentation of the region's labor markets into various contractual types of a nonpermanent nature is also a challenge. The self-employed are also generally unrepresented.

17 A. Wood. 1995. North-South Trade, Employment, and Inequality: Changing Fortunes in a Skill-Driven World. Oxford: Clarendon Press; New York: Oxford University Press. 
28. Some have also observed that many occupations that exist today could not even have been conceived by most people 25 years ago, such as web designers, cloud management, or social media management. Consider the World Bank's projection of jobs susceptible to automation as a "partial equilibrium" statement having little to do with new and perhaps unforeseen jobs created in the future in Figure 3.

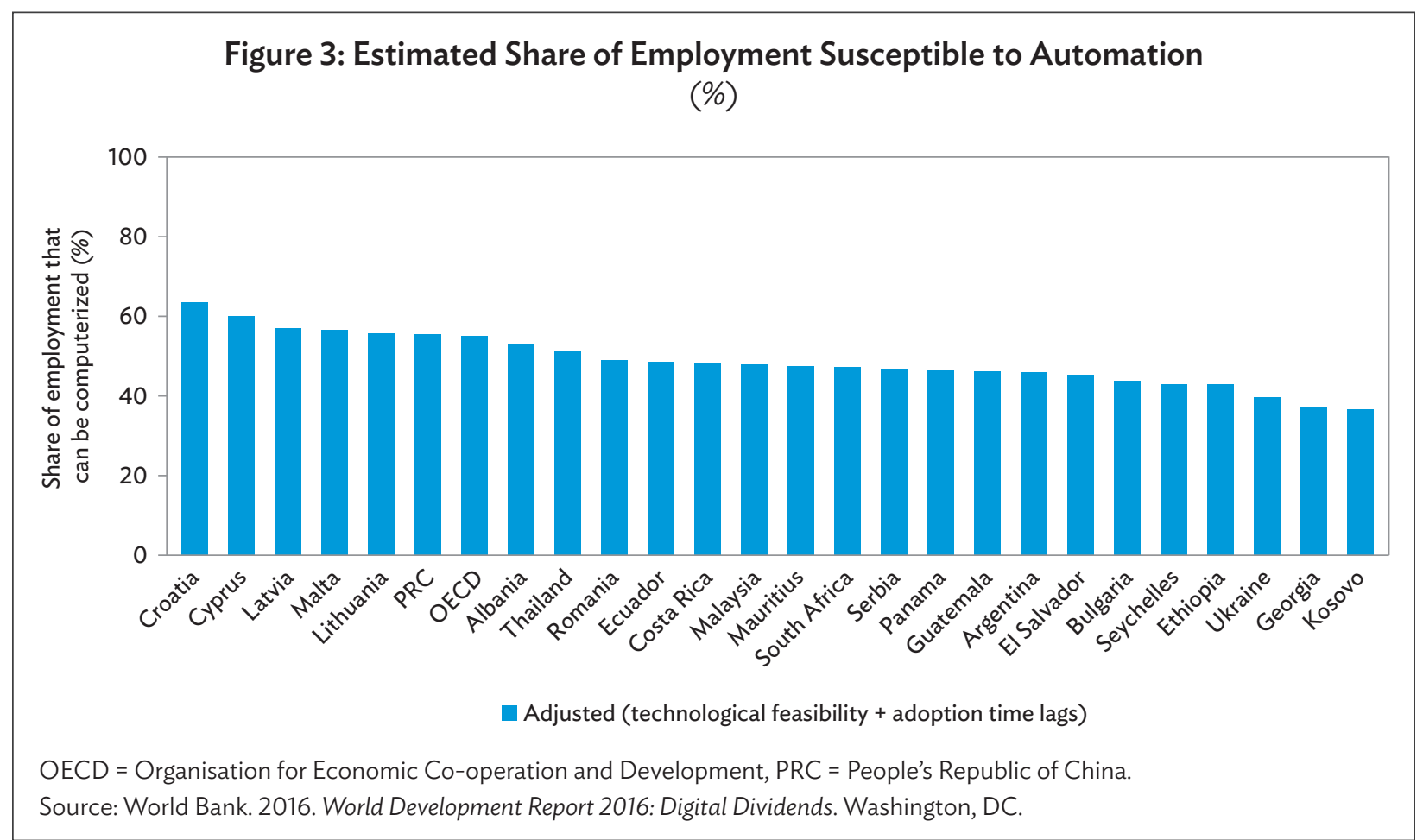

\section{SOCIAL PROTECTION WITHIN THE FOURTH INDUSTRIAL REVOLUTION CONTEXT}

29. Developed country labor markets have witnessed a rising share of workers on part-time contracts, temporary contracts, and work once done by employees now done by self-employed workers-NSFEs. Work of this nature often does not have the protection of a standard form of employment, such as severance pay, maternity leave, sick leave, workers' compensation, and contributions to old-age pensions. A social protection gap has consequently arisen.

30. Despite Asia and the Pacific's familiarity with NSFEs, gaps in social protection attached to labor market participation persist in the region. Casual labor, part-time and temporary workers, and contract labor are usually excluded from protections related to income security and work-related social insurance or legal obligations incumbent upon the employer (e.g., maternity leave, paid leave, and overtime). The principal barriers to social protection are legal thresholds preventing access to entitlements for NSFEs. For example, Viet Nam has a minimum employment period of 3 months for social insurance coverage as of 2018. ${ }^{18}$ Table 3 outlines exclusions for workers in NSFEs regarding social protection coverage and ways to extend the coverage.

18 International Labour Organization. 2016. Non-Standard Forms of Employment around the World: Understanding Challenges, Shaping Prospects. Geneva. 
Table 3: Extending Social Insurance Coverage in Asia and the Pacific

\begin{tabular}{|c|c|c|}
\hline $\begin{array}{l}\text { Nonstandard Form } \\
\text { of Employment }\end{array}$ & Coverage and Exclusion & Solutions \\
\hline Part-time & $\begin{array}{l}\text { - Covered if thresholds on } \\
\text { minimum hours/days are met. } \\
\text { - In case of multiple employers, } \\
\text { specific regulations may apply. } \\
\text { - Excludes marginal, part-time } \\
\text { workers from coverage. }\end{array}$ & $\begin{array}{l}\text { - Lower thresholds regarding working hours. } \\
\text { - Allow practical solutions for workers with multiple } \\
\text { employers and for those combining part-time } \\
\text { dependent employment with self-employment. }\end{array}$ \\
\hline Temporary & $\begin{array}{l}\text { - Covered if minimum duration of } \\
\text { employment is met. } \\
\text { - Usually excludes casual workers. }\end{array}$ & $\begin{array}{l}\text { - Lower thresholds regarding minimum duration of } \\
\text { employment. } \\
\text { - Allow for more flexibility in regard to the number of } \\
\text { contributions required to qualify for benefits; allow for } \\
\text { interrupted contribution periods. } \\
\text { - Enhance portability of entitlements between different } \\
\text { social security schemes to facilitate mobility between } \\
\text { jobs. } \\
\text { - Simplify administrative procedures for registration and } \\
\text { contribution payments. }\end{array}$ \\
\hline Temporary agency work & $\begin{array}{l}\text { - Covered through employing } \\
\text { agency, although thresholds } \\
\text { with regard to duration of } \\
\text { employment and working time } \\
\text { apply. }\end{array}$ & $\begin{array}{l}\text { - Ensure compliance with legislation, and introduce joint } \\
\text { liability. } \\
\text { - Measures taken to facilitate coverage for temporary and } \\
\text { part-time workers are likely to benefit temporary agency } \\
\text { workers as well. }\end{array}$ \\
\hline
\end{tabular}

Source: International Labour Organization. 2016. Non-Standard Forms of Employment around the World: Understanding Challenges, Shaping Prospects. Geneva.

\section{A. Protected Mobility}

31. The mobility, or portability, of social protection coverage will be important for labor market mobility. Mobility refers to a greater succession of jobs deviating from long-term employment security with a single employer, as well as more employers. A model of protected mobility must be tailored to the region. ${ }^{19}$

32. Income replacement protection must accompany a more mobile labor market, one in which there may be more frequent spells of nonemployment. Two empirical commonalities are relative to such social protection: a positive correlation between GDP and public spending on social protection, and a weaker correlation (i.e., a higher standard deviation) the poorer a country. In short, how much a government spends on social protection is a matter of political choice.

\section{B. Unemployment Insurance}

33. To facilitate labor market mobility, several studies have highlighted the need to move away from job protection through strict employment protection legislation. Recent literature has distinguished

19 "Protected mobility" is similar to "flexicurity," without being associated with the Nordic countries, or the belief, largely by trade unions and some left-of-center political parties, that the term emphasizes "flexi" over "curity." Protected mobility and flexicurity share the conceptual basis of removing constraints to labor market while ensuring that employees are protected through all phases of that mobility, except for income replacement for periods of nonemployment, portability of pensions, and assurance of access to effective voice mechanisms. 
between burdensome procedural rules surrounding hiring and firing and indemnifying job loss through severance pay, finding that severance pay can actually help reallocate labor. ${ }^{20}$

34. Lessening obstacles to mobility by lightening the burden placed solely at the micro level for employment protection is also the aim of unemployment insurance systems, which provide income replacement of varying generosity and duration of varying length, as well as several conditions that qualify the employee to receive the benefit. However, even developed countries' well-established unemployment insurance systems are not equipped to handle more frequent spells of unemployment, as contribution thresholds are supposed to trigger access to the benefit. Such unemployment insurance systems are also not equipped to handle more diverse labor market statuses, such as temporary wage work or self-employment.

35. There are problems related to creating such unemployment insurance benefits in many developing countries. Primarily, unemployment insurance applies to wage earners rather than the selfemployed; those in the formal economy; and those in regular, full-time jobs. This would exclude much of the labor force in Asia and the Pacific. Unemployment insurance entitlements typically require that the person has no work, is available to work, and is actively seeking work. Collecting and assessing this information would strain the administrative capacities of many developing countries and could become an opportunity for corruption of a rent-sharing nature.

36. Moreover, unemployment insurance systems work best where unemployment is a discrete phenomenon, that is, where labor market status is binary (i.e., employed or unemployed). Unemployment in developing countries, however, tends to be a continuous variable. Because of large informal economies with low barriers to entry, the unemployed can generate income from work in the informal economy (i.e., be employed) while receiving unemployment insurance, given the inadequacy of monitoring capacity by public authorities.

37. Finally, unemployment in many developing countries affects the nonpoor, not the poor. Unemployment insurance could have regressive distributional effects in such a context.

\section{Citizenship Approach}

38. While unemployment insurance is neither widespread nor inclusive where it exists in Asia and the Pacific, the effort to provide income protection for children, health, and old-age pensions is more extensive. The most successful of these programs are based on the concept of social protection as a right of citizenship, as it often is in developed countries. ${ }^{21}$ The concept extends to that of a social pension, a usually unconditional and noncontributory old-age income transfer. Its universality is contrasted with the narrower approach of targeting poverty relief in Figure 4.

39. There are other ways of delivering social protection to those most in need, short of fully developed social security apparatus. Cash transfer programs, of which the best known are in Latin America, have also received widespread attention as a tool for protection and poverty reduction. India's Mahatma Gandhi National Rural Employment Guarantee scheme is often mentioned as a successful conditional cash transfer program. The employment guarantee is, in fact, time-bound (i.e., 100 days) per household and thus resembles a conditional cash transfer program.

20 ADB. 2018. Asian Development Outlook 2018: How Technology Affects Jobs. Manila.

21 S. Kidd. 2017. Social Exclusion and Access to Social Protection Schemes. Journal of Development Effectiveness. 9 (2). pp. 214-244. 


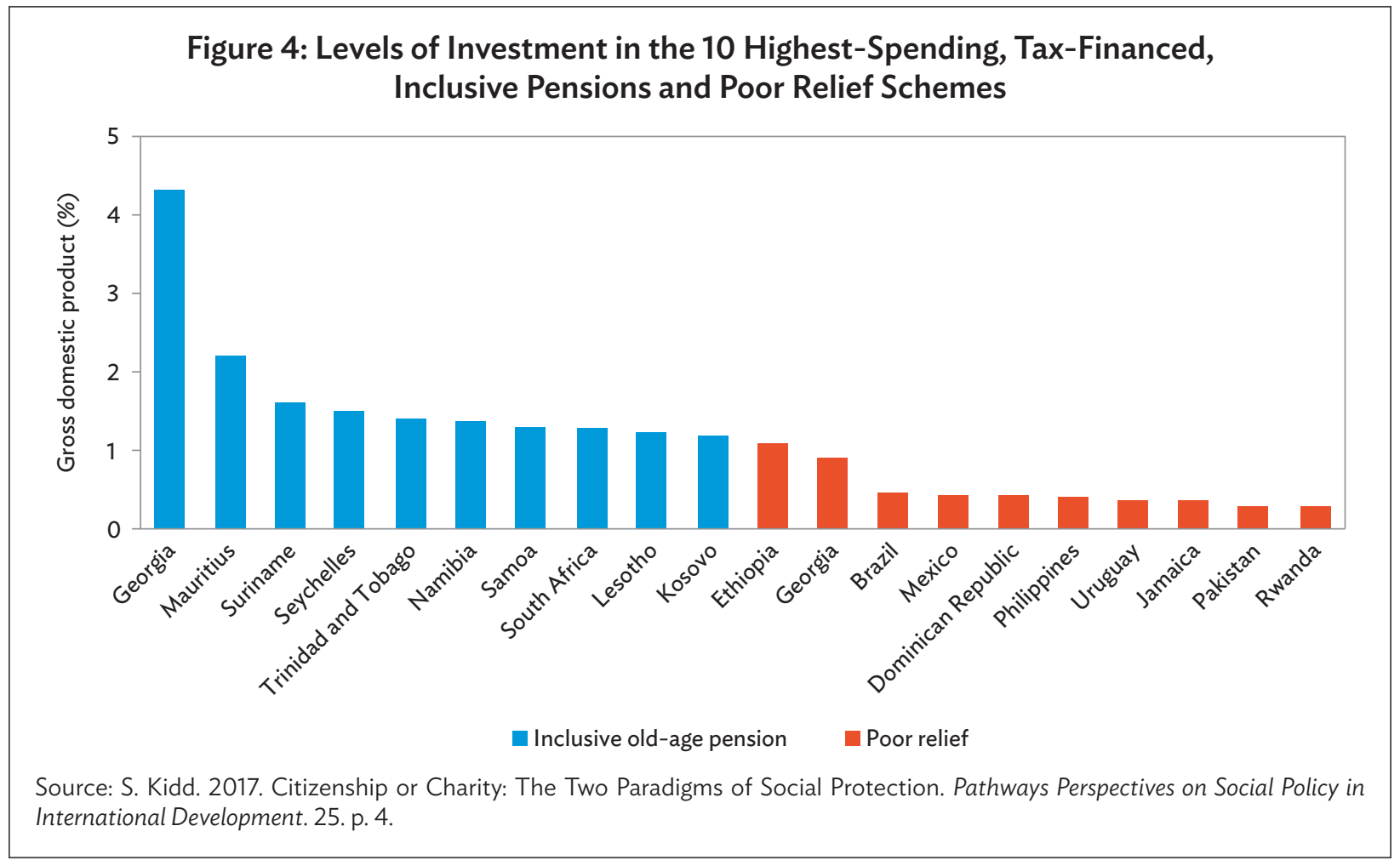

40. Another initiative, endorsed by the United Nations, is the concept of a global social floor, or minimal social protection provided to all. The concept of a basic income as a right of citizenship has re-arisen in connection with the future of work debate and, in particular, the concern over the paucity of jobs that technological unemployment could incur. Universal basic income is a social security concept consisting of unconditional income paid by a government to all citizens, irrespective of whether they work. It can be a tool of reducing poverty, lessening inequality, and substituting various conditionalitybased welfare tools. There are ancillary benefits to an unconditional income guarantee, especially empowerment, or the freedom to make choices independent of conditionality-driven constraints. Moreover, conditionality-based benefits can impose penalties on labor force participation, as income earned outside of entitlements can result in such entitlements and a disincentive to work.

41. Skeptics of the universal basic income concept argue that an unconditional entitlement to income is itself a disincentive to work. There is some evidence for this, although the disincentive effect is directly proportional to the generosity of the guaranteed income. If the income transfer is minimal (e.g., below the poverty line), then disincentive effects are minimal, and it poses no constraints to labor market participation.

42. The interest in a universal basic income is unlikely to recede from the policy discussion, even if few countries have adopted the concept. One constraint is that, despite the consolidation and transfer of more disparate, conditionality-based welfare benefits, a universal and unconditional transfer would imply an increase in income tax rates. ${ }^{22}$

22 S. Devarajan. 2017. Three Reasons for Universal Basic Income. Brookings. 15 February. https://www.brookings.edu/blog/ future-development/2017/02/15/three-reasons-for-universal-basic-income/; and Basic Income Earth Network. https:// basicincome.org/. 


\section{SOCIAL PROTECTION AND EMPLOYMENT}

43. As employers increase their quotients of NSFEs, they are also backing away from the traditional model of partially employer-funded social protection that prevails in developed countries for standard, long-term contracts of work. The responsibility for social protection has thus been thrust back onto the individual worker.

44. In addition, as the content of work becoming untethered to a physical location, responsibility for social protection is becoming less clear, especially when such untethering also creates ambiguity over the nature of a contract (e.g., whether employment law or commercial law applies. For example, an independent contractor receives a fee for services rendered, whereas if $s /$ he were an employee, work would be covered under labor law relative, say to hours of work, overtime, sickness, pension contributions by the employer, employment security, etc.). While this is a trend in developed countries thanks to the Fourth Industrial Revolution, the labor force in Asia and the Pacific has been characterized by nonagricultural employment of a temporary and informal nature in which employer-provided social protection is unavailable. Ironically, both developed and developing countries are now finding themselves in a similar position regarding employment and social protection.

45. Developing countries and areas may be in better positions to escape the arduous reform of social security systems appropriate to a labor market of the past, and more capable of tackling the challenges of the new labor market more directly. Today, established social protection systems in developed countries are having trouble coping with the greater mobility and volatility of the new labor market in regard to the provision and portability of social protection coverage. The deterioration of job quality, as well as job scarcity, are why concepts such as universal basic income or other forms of conditional or unconditional transfer payments are seen as fundamental. For example, Brazil created the largest cash transfer program in the world, Bolsa Família, reaching 55\% of its poorest citizens, costing $30 \%$ less than more traditional aid programs, and lifting 36 million people out of extreme poverty. ${ }^{23}$

46. Those in NSFEs are most prone to deficits in their social protection. Contributory schemes for health and old-age pensions do exist, but there are very few schemes that address, for example, income replacement between projects, as, as has been noted, labor churning is becoming much more common. Similarly, the question arises of how those in NSFEs can acquire and update their skills in the absence of on-the-job or more formal training schemes usually associated with standard contracts of employment.

47. With work experiences of shorter duration, workers in NSFEs must acquire and update the learning and skills required to move from job to job. In the absence of employment security under standard employment contracts, however, there is little incentive for employers to invest in training. At present, OECD countries spend an average of 4\% of GDP on training and re-training. In Asia and the Pacific, where active labor market programs are dramatically underfunded, less than $1 \%$ of GDP is spent on such programs. ${ }^{24}$

23 J. Tepperman. 2016. Brazil's Antipoverty Breakthrough: The Surprising Success of Bolsa Família. Foreign Affairs. 95 (1).

24 ADB. 2018. Asian Development Outlook 2018: How Technology Affects Jobs. Manila. 
48. Moreover, for example, some countries in Asia and the Pacific are aging. Older workers are likely to see the erosion of their skill sets in this era of rapid technological change. Thus, re-training to enhance employability becomes vital, or it is likely that labor markets will witness widening labor market segmentation between those with and without relevant skills, despite years on the job.

49. Note that technological change in the Fourth Industrial Revolution is skill-biased. It is biased upward, whereas technological change in the 19th and early 20th centuries was biased downward, meaning that the new jobs created were usually repetitive tasks, lower-skilled components of what was the more robust array of skills required by a master craftsperson. The upside of this de-skilling was the economies of scale afforded by mass production and job opportunities for the many. Yet today, vacancies for skilled labor take longer to fill in this region than in any other region of the world, with the exception of Latin America.

50. Today, however, the best jobs require advanced cognitive and behavioral skills, as well as creative and problem-solving skills with digital literacy. A disproportionately high number of leading entrepreneurs in the digital economy attended Montessori preschools where individual creativity and problem solving are emphasized. ${ }^{25}$ In Asia and the Pacific, with the exception of Mongolia and Kazakhstan, however, spending on early childhood education is very low:

...even when basic education systems are strong and of good quality, the changing demand for skills in the labor market is creating new challenges to pedagogical emphasis and curriculum content. For example, creative problem solving is a cognitive skill increasingly required in workplaces undergoing rapid technological change. Yet education systems in East Asia Pacific countries often emphasize memorization. For example, Viet Nam, a country with nearly universal primary school enrolment, faces this challenge in the kind of cognitive skills its education system produces. Fifth graders do well on math problems requiring the application of known rules, but they falter when required to apply the same mathematical principles to new contexts. ${ }^{26}$

51. A whole-of-life or life-cycle approach visualizes social protection as not confined to the active labor market (Figure 5):

New systems will need to address gaps in social protection across typical life events including periods of education, raising families, work including career gaps, retirement, and later elder care. Systems will need to provide sufficient flexibility to support individuals following substantially different life and career paths while maintaining some inter-group equity, and bolster individual resilience. ${ }^{27}$

25 E. Brynjofsson and A. McAfee. 2016. The Second Machine Age: Work, Progress, and Prosperity in a Time of Brilliant Technologies. Cambridge, MA: MIT Press.

26 World Bank. 2016. World Development Report 2016: Digital Dividends. Washington, DC.

27 World Economic Forum. 2017. The Global Risks Report 2017. Geneva. 


\begin{tabular}{|c|c|c|}
\hline \multicolumn{3}{|c|}{ Figure 5: Social Protection Needs over a Life Cycle } \\
\hline & Age & \\
\hline $\begin{array}{l}\text { Description: Childhood } \\
\text { Social protection needs: Education and health care }\end{array}$ & $\begin{array}{l:}18 \\
18 \\
1 \\
18-22\end{array}$ & $\begin{array}{l}\text { Description: University/College } \\
\text { Social protection needs: No work-based protections- } \\
\text { need protection against adverse life events (health, } \\
\text { disability) }\end{array}$ \\
\hline $\begin{array}{l}\text { Description: Series of unpaid/low paid internships } \\
\text { Social protection needs: Limited work-based } \\
\text { protections-need protection against adverse life events } \\
\text { (health, disability) }\end{array}$ & $25-28$ & $\begin{array}{l}\text { Description: Entry to full-time workforce } \\
\text { Social protection needs: Start to contribute to social } \\
\text { protection systems. Access to employment-based } \\
\text { benefits. Protection against low income (income } \\
\text { supplements, etc.) }\end{array}$ \\
\hline $\begin{array}{l}\text { Description: Series of roles-within and between } \\
\text { corporations } \\
\text { Social protection needs: Period of contribution }\end{array}$ & $\begin{array}{l:c}1 \\
1 \\
129-35 \\
1\end{array}$ & $\begin{array}{l}\text { Description: Career break-family formation } \\
\text { Social protection needs: Some protection of income } \\
\text { (maternity and/or paternity coverage) }\end{array}$ \\
\hline $\begin{array}{l}\text { Description: Part-time employment-ending in } \\
\text { redundancy } \\
\text { Social protection needs: Protection against adverse life } \\
\text { events (unemployment, health, disability) }\end{array}$ & $37-4$ & $\begin{array}{l}\text { Description: Re-training for new role(s) } \\
\text { Social protection needs: Support in education and re- } \\
\text { training (likely to become a lifelong process as skill needs } \\
\text { change) }\end{array}$ \\
\hline $\begin{array}{l}\text { Description: Return to full-time workforce } \\
\text { Social protection needs: Returning to be net contributor }\end{array}$ & $43-49$ & $\begin{array}{l}\text { Description: Career break } \\
\text { Social protection needs: Protection against adverse life } \\
\text { events (health, disability) }\end{array}$ \\
\hline $\begin{array}{l}\text { Description: Series of interim contract roles } \\
\text { Social protection needs: Access to protections similar } \\
\text { to those in full-time employment. Requirement to } \\
\text { contribute }\end{array}$ & $51-5$ & $\begin{array}{l}\text { Description: Period of illness-unable to work } \\
\text { Social protection needs: An appropriate income during } \\
\text { period of disability }\end{array}$ \\
\hline $\begin{array}{l}\text { Description: Series of consulting roles } \\
\text { Social protection needs: Access to protections similar to } \\
\text { those in full-time employment }\end{array}$ & $\begin{array}{l}60-69 \\
70-75 \\
1\end{array}$ & $\begin{array}{l}\text { Description: Gradual exit from workforce } \\
\text { Social protection needs: Ability to supplement } \\
\text { decreasing employment income with access to } \\
\text { retirement benefits }\end{array}$ \\
\hline $\begin{array}{l}\text { Description: Full-time retirement } \\
\text { Social protection needs: Payment of retirement benefit }\end{array}$ & $76-85$ & $\begin{array}{l}\text { Description: Elder care } \\
\text { Social protection needs: Financing of periods in } \\
\text { residential care or with home support }\end{array}$ \\
\hline
\end{tabular}

Source: World Economic Forum. 2017. The Global Risks Report 2017. Geneva. p. 37. 


\section{CONCLUSIONS}

52 Undeniable progress has been made in the labor markets of Asia and the Pacific.; earnings have grown, as has wage employment. There has been a historic, impressive decline in poverty, particularly extreme poverty. On the whole, Asia and the Pacific enjoys a higher employment rate than other developing regions. By a standard earnings measure, its middle class has grown. However, development challenges remain. High informality persists, as does subsistence or distress self-employment, pointing to a deficit of good jobs and good job creation.

53. The majority of the region's population has not yet entered the era of the Fourth Industrial Revolution; half of the global population is not connected to the internet, many of whom are in Asia and the Pacific, and $\mathbf{4 0 0}$ million in the region do not have access to an electricity grid. The basic laws of economics are still binding (e.g., labor surplus where it remains is a disincentive to invest in new technologies). The relative price mechanism is still a variable, which has demonstrated that the future of work is the present of work for some time to come.

54. The net employment effect of the eventual Fourth Industrial Revolution is unknowable in Asia and the Pacific. How its labor markets will respond to new technologies arises from the difficulty, if not impossibility, of predicting new job growth and the grey area of whether technology substitutes for or complements human labor. Yet the Fourth Industrial Revolution has significant implications for the quantity, quality, location, and nature of work everywhere. The optimal path for attaining the greatest benefit from the digital economy is to prevent excessive obstacles to factor mobility, including labor, such as inadequacies in education, training, and retraining systems, as well as the absence of social protection to enable this.

55. Ironically, the current structure of developing labor markets, such as across Asia and the Pacific, consist of elements, like NSFEs, with which many developed economies are currently confronted in policy terms. Many economies in Asia and the Pacific are working toward advancing their agendas of work-related social protection to the categories of employment that they have long had. This is a prelude to adjusting these forms of work toward greater protection, and, for some, technologically induced greater labor market mobility. These policy points are independent of policy support to the growth of standard wage-earning growth, and the education and training policies that may best support this. 


\section{Work and Social Protection in Asia and the Pacific during the Fourth Industrial Revolution}

This working paper posits that the Fourth Industrial Revolution, driven by the expanding digital economy, will bring significant changes to Asia and the Pacific's labor market-one that is yet to come to terms with its social protection challenges-in the quantity, quality, location, and nature of work. The optimal path for attaining the greatest benefit from the digital economy is to prevent excessive obstacles to factor mobility such as inadequacies in education, training, and retraining systems, as well as the absence of social protection such as unemployment insurance.

\section{About the Asian Development Bank}

ADB is committed to achieving a prosperous, inclusive, resilient, and sustainable Asia and the Pacific, while sustaining its efforts to eradicate extreme poverty. Established in 1966, it is owned by 68 members -49 from the region. Its main instruments for helping its developing member countries are policy dialogue, loans, equity investments, guarantees, grants, and technical assistance. 